$\begin{array}{cl}\text { Türkiye Tarımsal Araştırmalar Dergisi } & \text { Turk J Agric Res } \\ \text { dergipark.gov.tr/tutad } & \text { 2017, 4(1): 10-23 } \\ \text { O TÜTAD } & \text { ISSN: 2148-2306 } \\ \text { e-ISSN: 2528-858X } & \text { doi: 10.19159/tutad.300586 }\end{array}$

\title{
Çinko Uygulamasının Makarnalık Buğday Çeşitlerinde Verim ve Bazı Tarımsal Özellikler Üzerine Etkisi
}

\author{
Hatun BARUT ${ }^{{ }^{*}}$, Tuğba ŞìŞ̧EK ${ }^{\mathbf{2}}$, Sait AYKANAT ${ }^{\mathbf{1}}$ \\ ${ }^{1}$ Doğu Akdeniz Tarımsal Araştırma Enstitüsü Müdürlüğü, Adana, TÜRKIYE \\ ${ }^{2}$ Antepfistığ Araştırma Enstitüsü Müdürlüğ̈̈, Gaziantep, TÜRKIYYE
}

\begin{abstract}
Geliş Tarihi/Received: 03.08 .2016
Kabul Tarihi/Accepted: 29.12.2016

*Sorumlu Yazar/Corresponding author: baruthatun@yahoo.com

Özet: Bu çalışma, Çukurova Bölgesi’nde yaygın olarak ekimi yapılan bazı makarnalık buğday çeşitlerinin gelişimi, verimi ve verim unsurları üzerine çinko uygulamalarının etkisini tespit etmek amacıyla yürütülmüştür. Araştırmada, Amanos-97 ve Fuatbey-2000 makarnalık buğday çeşitleri kullanılmıştır. Tarla denemeleri; topraktan ve toprak+yapraktan olmak üzere çinkonun iki farklı uygulama şekli ile yürütülmüştür. Her iki denemede; $0,0.5,1,2,3 \mathrm{ve} 4 \mathrm{~kg} \mathrm{Zn} \mathrm{da}^{-1}$ saf çinko dozları topraktan uygulanmıştır. Yapraktan çinko uygulamalarında \% $0.4^{\prime}$ lük $\mathrm{ZnSO}_{4} .7 \mathrm{H}_{2} \mathrm{O}$ solüsyonu kullanılmıştır. Araştırma sonucunda elde edilen verilere göre; makarnalık buğdaylarda toprak ve toprak+yapraktan çinko uygulamalarının, bitki boyu, biyolojik verim, sap verimi, hasat indeksi, tane verimi üzerine istatistiki olarak etkili olmadı ̆̆ı belirlenmiștir. Topraktan çinko uygulamaları, bin tane ağırlı̆̆ açıdan \% 1 düzeyinde önemli bulunmuştur. Araştırma sonucunda; toprakta 0.23-0.25 ppm çinko varlığında, topraktan dekara 1-2 kg çinko uygulamasının, tane çinko konsantrasyonu, verim ve verim unsurları üzerine olumlu etki yaptı̆̆ belirlenmiştir. Tane çinko konsantrasyonu üzerine ise çinkonun toprak+yaprak uygulamasının daha etkili olduğu belirlenmiştir.
\end{abstract}

Anahtar Kelimeler: Makarnalık buğday, çinko, toprak, verim

\section{Effects of Zinc Treatments on Yield and Some Agronomic Traits of Durum Wheat Cultivars}

\begin{abstract}
This study was carried out to determine the effects of zinc applications on the development, yield and yield components of widespread durum wheat cultivars in Çukurova Region. Amanos-97 and Fuatbey-2000 durum wheat cultivars were used in the research. Field experiments were performed by two different zinc application methods; via soil and via soil+foliage. In both trials, $0,0.5,1,2,3$, and $4 \mathrm{~kg} \mathrm{Zn} \mathrm{da}^{-1}$ pure zinc doses were applied to the soil. $0.4 \%$ $\mathrm{ZnSO}_{4} .7 \mathrm{H}_{2} \mathrm{O}$ solution was used for foliar zinc applications. As a result of the research, it has been determined that application of zinc via soil and via soil+foliage is not statistically effective on plant height, biological yield, stem yield, harvest index and grain yield of durum wheat. The application of zinc via soil were found statistically significantly effective at $1 \%$ level on thousand grains weight, number of spikes per square meter and zinc concentration of the grains. As a result of the research, it has been determined that when basal soil $\mathrm{Zn}$ content was $0.23-0.24 \mathrm{ppm}$, application of 1-2 $\mathrm{kg} \mathrm{da}^{-1}$ of zinc via soil has positive effects on grain zinc concentration, yield and yield components. It has also been determined that soil+foliar application of zinc is more effective on zinc concentration of grains.
\end{abstract}

Keywords: Durum wheat, zinc, soil, yield 


\section{Giriş}

Çinko (Zn) noksanlığının ve diğer mikro element noksanlıklarının özellikle gelişmekte olan ülkelerde çok çarpıcı boyutlarda olduğu bilinmektedir. Çinko noksanlığının dünyada yaygın olmasının ana nedeni olarak insanların fazlasıyla tahıl kökenli gıdaları tüketmesi gösterilmiştir. Dünyadaki tarım alanlarının \% 30'unda Zn eksikliği olduğu belirlenmiştir (Sillanpaa, 1982). Eksikliğin en sık görüldüğü bölgeler; Akdeniz Bölgesi, Güney Doğu Asya ve Doğu Asya ülkeleri ve Avusturalya'dır. Yapılan çalışmalarda, Çin'de 20 milyon, Hindistan'da 30 milyon, Türkiye'de 14 milyon, Avusturalya'da en az 10 milyon ve Bangladeş'te 8 milyon hektar işlenebilir toprakta çinko eksikliğinin olduğu saptanmıştır (White ve Zasoski, 1999; Çakmak, 2008).

Buğday, gelişmekte olan birçok ülkede en önemli temel enerji kaynağıdır. Ancak buğday tanesinin Zn konsantrasyonu (genellikle 25-30 ppm), insanların sağlıklı beslenebilmesi için ihtiyaç duyulan veya tavsiye edilen seviyeden çok düşüktür (Erdal ve ark., 2002; Çakmak, 2008). Türkiye, İran, Hindistan ve Avusturalya'daki Zn eksikliği olan topraklarda da gözlemlendiği gibi, buğdayda $\mathrm{Zn}$ gübrelemesi yapılmaksızın $\mathrm{Zn}$ yönünden zayıf topraklarda yetiştirildiğinde elde edilen tanelerin $\mathrm{Zn}$ konsantrasyonu $10-15$ mg kg-1 seviyesinden daha düşük düzeylere inebilmektedir (Graham ve ark., 1992; Çakmak ve ark., 1999; Erdal ve ark., 2002; Alloway, 2008). İnsan sağlığ1 açısından, tane çinko konsantrasyonunda en az 10 mg kg ${ }^{-1}$ lık bir artışın sağlanması gerekmektedir (White ve Broadley, 2005; Ortiz-Monasterio ve ark., 2007; Pfeiffer ve McClafferty, 2007; Çakmak, 2008). Son dönemlerde yapılan araştırmalara ait bulgular $\mathrm{Zn}$ ve vitamin A eksikliğinin, dünya çapında çocuklar arasında gözlemlenen en ciddi besin noksanlıkları olduğunu ortaya koymuştur. Bu beslenme sorunları 5 yaş altı çocuklarda ölümlerin en önemli nedeni olarak gösterilmiştir (Black ve ark., 2008). Çinko eksikliğinin önemli bir halk sağlığı problemi olduğu belirlenen ülkelerde, günlük ihtiyaç duyulan kalorinin önemli bir kısmının tahıla dayalı besinlerden sağlandığı belirtilmiştir (Brown ve ark., 2004; Çakmak, 2008; Gibson ve ark., 2008).

Çinko birçok bitki türünde vejetatif dokulardan remobilize edilebilmektedir (Waters ve Grusak, 2008). Uluslararası bir proje kapsamında (Harvest Plus Zinc Fertilizer Project) 2008-2011 yıllar1 arasında farklı ülkelerde yürütülmüş olan biyofortifikasyon çalışmalarıyla tanede $\mathrm{Zn}$ konsantrasyonları \% 0-22 arasında arttırılabilmiştir (Çakmak, 2012). Buğdayın Zn ile zenginleştirilmesinde genetik ve agronomik yaklaşımlar tavsiye edilmektedir (Bouis ve Welch, 2010). Yapraktan Zn uygulamaları da buğday tanesindeki Zn içeriğini önemli oranda artırmaktadır (Pahlavan-Rad ve Pessarakli, 2009; Çakmak ve ark., 2010a; Zou ve ark., 2012; Xue ve ark., 2012). Yapraktan ve kökten Zn uygulamaları hem bitkisel üretimdeki hem de insan sağlığı ile ilgili Zn eksikliğini gidermede kısa vadede etkili bir çözüm olarak görülmektedir (Çakmak, 2008; Manzeke ve ark., 2014; Prasad ve ark., 2014). Agronomik yollarla biyofortifikasyon hedeflendiğinde bunu topraktan gübre uygulamaları yaparak artırmaktansa, yapraktan uygulama daha ucuz ve verimli olmakta; ayrica, bu yolla daha az gübre gerekmektedir (Singh ve ark., 2015). Buğday bitkisinin geç gelişim dönemlerindeki (çiçeklenme süresince ve erken süt olum döneminde) yapraktan $\mathrm{Zn}$ uygulamaları tane Zn konsantrasyonunu artırmada etkili bulunmakta, fakat topraktan $\mathrm{Zn}$ uygulamaları daha az etkili olmaktadır (Çakmak ve ark., 2010b; Zou ve ark., 2012).

Son yıllarda yapılan araştırmalarda olduğu gibi; tahıl tanelerinin çinko içeriğinin yükseltilmesi, insanlarda beslenme yoluyla ortaya çıkan çinko eksikliğine bağlı sağlık problemlerini azaltmada önemli bir küresel strateji olarak karşımıza çıkmaktadır. $\mathrm{Bu}$ çalışma ile Çukurova'da yaygın olarak ekimi yapılan makarnalık buğday çeşitlerine; toprak, toprak+yapraktan çinko uygulamasının verim, verim unsurları ve tane çinko konsantrasyonu üzerine etkisi araştırılmıştır.

\section{Materyal ve Yöntem}

$\mathrm{Bu}$ araştırma; Doğu Akdeniz Tarımsal Araştırma Enstitüsü'ne ait Doğankent lokasyonunda, 20052006 ve 2006-2007 buğday ekim sezonlarında iki yıl süreyle yürütülmüştür.

\subsection{Araştırma yerinin iklim özellikleri}

Araştırmanın yürütüldüğü 2005-2006 yetiştirme sezonunda toplam $414.3 \mathrm{~mm}, 2006-$ 2007 yıllarında ise $657.0 \mathrm{~mm}$ yağış düşmüştür. Buğdayın yetişme sezonu boyunca yıllar arasında yağışın dağılımında farklılıklar olmuş; çalışmanın birinci yılında uzun yıllar ortalamasının altında toplam yağış değeri kaydedilirken; ikinci yetiştirme döneminde ise, uzun yıllar ortalamasının biraz üzerinde yağış düştüğü görülmüştür. Sıcaklık ve nispi nem açısından ise her iki yetişme sezonu boyunca uzun yıllar ortalamalarına yakın değerler tespit edilmiştir (Tablo 1). 
Tablo 1. Adana ili; buğday yetiştirme sezonundaki uzun yıllar (1980-2006) ve deneme yılları (2005-2006, I. y11; 2006-2007, II. y1l) bazı iklim verileri

\begin{tabular}{|c|c|c|c|c|c|c|c|c|c|}
\hline \multirow[b]{2}{*}{ Aylar } & \multicolumn{3}{|c|}{ Sicaklik $\left({ }^{\circ} \mathrm{C}\right)$} & \multicolumn{3}{|c|}{ Yağış (mm) } & \multicolumn{3}{|c|}{ Nispi nem (\%) } \\
\hline & Uzun yillar & I. $\mathrm{y} 1 \mathrm{l}$ & II. y1l & Uzun yillar & I. y1l & II. y1l & Uzun yillar & I. y1l & II. y1l \\
\hline Ekim & 21.6 & 19.8 & 21.0 & 43.5 & 37.9 & 156.3 & 60 & 61 & 71 \\
\hline Kasim & 15.3 & 13.9 & 13.2 & 73.9 & 64.6 & 91.5 & 63 & 67 & 65 \\
\hline Aralık & 11.1 & 12.1 & 9.3 & 124.4 & 64.1 & 0.0 & 67 & 70 & 58 \\
\hline Ocak & 9.7 & 8.8 & 8.7 & 109.4 & 36.3 & 34.1 & 65 & 63 & 63 \\
\hline Şubat & 10.4 & 10.6 & 11.2 & 88.9 & 131.6 & 127.0 & 65 & 73 & 72 \\
\hline Mart & 13.3 & 14.1 & 14.2 & 65.8 & 46.2 & 75.7 & 65 & 76 & 70 \\
\hline Nisan & 17.5 & 18.5 & 16.6 & 52.5 & 9.3 & 115.4 & 67 & 71 & 64 \\
\hline May1s & 21.7 & 22.4 & 23.5 & 47.0 & 19.8 & 32.0 & 66 & 69 & 70 \\
\hline Haziran & 25.6 & 26.0 & 26.0 & 20.6 & 4.5 & 25.0 & 67 & 73 & 69 \\
\hline Toplam & & & & 626.0 & 414.3 & 657.0 & & & \\
\hline
\end{tabular}

2006-2007 ekim yılı 13 Kasım-20 Ocak tarihleri arasında yağış düşmemiştir.

Tablo 1'den görüleceği üzere; denemenin birinci yılında, makarnalık buğdayların ekili olduğu alanda, kardeşlenme zamanında şiddetli yağış (Şubat ayında $131.6 \mathrm{~mm}$ ) nedeniyle araziye gidilememiş ve kardeşlenme aşamasında yapılması gereken yapraktan çinko uygulaması yapılamamıştır. Denemenin ikinci yılında; Aralık, Ocak ve Şubat ayları içinde hiç yağış düşmemiş ve kuraklık stresi yaşanmış; Şubat sonuna kadar hemen hemen hiç bitki çıkışı sağlanamamıştır. Şubat ayının sonunda düşen yağışlardan sonra buğday çıkışları başlamıştır. Bu nedenle buğdayın gelişim sezonları değişmiş, normalde Ocak-Şubat aylarında kardeşlenmeyi tamamlayan bitkilerde bu yıl Şubat sonunda ancak çıkışlar olabilmiştir. Daha sonraki aylarda, hava sicaklığının artmasıyla, buğdaylar hızlı bir gelişme dönemine girmiştir. Buğdayın gelişimi ve verimi üzerinde Nisan ve Mayıs yağmurları etkili olmuştur.

\subsection{Araştırma toprağının bazı fiziksel ve kimyasal özellikleri}

Araştırma alanı topraklarının; killi-tınlı bünyeli, hafif alkali reaksiyonlu, hafif tuzlu, kireç içeriği yüksek, organik maddesi düşük, alınabilir fosfor (P) içeriği düşük, alınabilir potasyum (K) içeriği yüksek ve ekstrakte edilebilir $\mathrm{Zn}$ içeriğinin ise az düzeyde olduğu belirlenmiştir (Tablo 2).

Tablo 2. Doğankent lokasyonuna ait toprakların bazı fiziksel ve kimyasal özellikleri

\begin{tabular}{|c|c|c|}
\hline Toprak özelliği & I. y1l & II. y1l \\
\hline Kil, \% & 27 & 36 \\
\hline Silt, \% & 29 & 39 \\
\hline Kum, \% & 43 & 26 \\
\hline Tekstür sınıfı & Killi tın & Killi tın \\
\hline $\mathrm{pH}$ & 7.85 & 7.87 \\
\hline Toplam tuz, mmhos $\mathrm{cm}^{-1}$ & 0.150 & 0.280 \\
\hline Kireç $\left(\mathrm{CaCO}_{3}\right), \%$ & 15.2 & 14.2 \\
\hline Organik madde, $\%$ & 1.4 & 1.9 \\
\hline Alinabilir $\mathrm{P}, \mathrm{kg} \mathrm{P}_{2} \mathrm{O}_{5} \mathrm{da}^{-1}$ & 3.0 & 3.0 \\
\hline Alınabilir $\mathrm{K}, \mathrm{kg} \mathrm{K}_{2} \mathrm{O} \mathrm{da}^{-1}$ & 128 & 93 \\
\hline Ekstrakte edilebilir Zn, ppm & 0.23 & 0.25 \\
\hline
\end{tabular}

\subsection{Tarla denemelerinin kurulması ve yürütülmesi}

Araştırmada; Doğu Akdeniz Tarımsal Araştırma Enstitüsü tarafindan geliştirilen Amanos-97 ve Fuatbey-2000 makarnalık buğday çeşitleri kullanılmış olup; tüm sahil kuşağında ve Güneydoğu Anadolu Bölgesi'nde yetiştirilebilen yazlık tabiatlı çeşitlerdir.

Araştırmada, topraktan ve toprak+yapraktan çinko uygulamasını içeren iki farklı tarla denemesinde; çinko dozları ve çeşitler araştırmanın konusunu teşkil etmiştir. Her iki deneme, tesadüf bloklarında bölünmüş parseller deneme desenine göre 3 tekerrürlü olarak kurulmuştur. Buna göre; çinko dozları ana parsellere, çeşitler ise alt parsellere tesadüfi olarak dağıtılmıştır. Alt parsellerde 8 sıra halinde ekim yapılmış olup, tüm çeşitlerde ekim sıklığı 400 tane $\mathrm{m}^{-2}$ olarak alınmıştır.

Hem toprak ve hem de toprak+yaprak çinko denemelerinde; çinkonun $0,0.5,1,2,3$, ve $4 \mathrm{~kg} \mathrm{Zn}$ $\mathrm{da}^{-1}$ saf çinko dozları uygulanmıştır. Topraktan çinko uygulamasında; çinko dozları ekimden hemen önce toprak yüzeyine püskürtülüp, diskli tırmık ile toprağa karıştırılmış olup; Zn kaynağ 1 olarak \% 22'lik çinko sülfat $\left(\mathrm{ZnSO}_{4} .7 \mathrm{H}_{2} \mathrm{O}\right)$ kullanılmıştır. Yapraktan çinko uygulamalarında

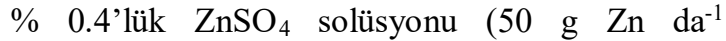
hesabıyla) kullanılmış ve parsellere sırt pülverizatörü ile uygulanmıştır.

Yapraktan solüsyon uygulamaları, kardeşlenme ve sapa kalkma dönemlerinde 15 gün arayla ikişer kez uygulanmıștır. Taban gübresi olarak; ekimle beraber saf $6 \mathrm{~kg} \mathrm{~N} \mathrm{da}^{-1}$ (Amonyum sülfat, \% $21 \mathrm{~N}$ ) ve fosfor (P)'lu gübrenin tamamı, saf $6 \mathrm{~kg} \mathrm{P}_{2} \mathrm{O}_{5}$ $\mathrm{da}^{-1} \quad(\%$ 42-44'lük triple süper fosfat) olarak uygulanmıștır. Buğdaya kardeşlenme aşamasında ise ilave olarak $10 \mathrm{~kg} \mathrm{~N} \mathrm{da}^{-1}$ düşecek şekilde üre $(\% 46 \mathrm{~N})$ verilmiştir. 


\section{4. Ölçüm, analiz ve değerlendirme}

Hasat sırasında ve sonrasında; bitki boyu $(\mathrm{cm})$, başak sayısı (adet $\left.\mathrm{m}^{-2}\right)$, biyolojik verim $\left(\mathrm{kg} \mathrm{da}^{-1}\right)$, sap verimi $\left(\mathrm{kg} \mathrm{da}^{-1}\right)$, hasat indeksi (\%), bin tane ağırlı̆̆ $(\mathrm{g})$, tane verimi $\left(\mathrm{kg} \mathrm{da}^{-1}\right)$ ve tane çinko konsantrasyonu (ppm) (Çakmak ve ark., 1996) ölçüm ve analizleri yapılmıştır.

Toprak bünyesi, Bouyoucus (1952); toprakların elektriksel iletkenlik (EC) değeri, Anonymous (1954); toprak pH's1 ve organik madde içeriği, Jackson (1959); kireç içeriği, Çağlar (1949); toprakların alınabilir $\mathrm{P}$ içeriği, Olsen ve ark. (1954); alınabilir K içeriği, Jackson (2005), ekstrakte edilebilir $\mathrm{Zn}$ içerikleri ise, Lindsay ve Norwell (1978) tarafindan bildirilen esaslar çerçevesinde belirlenmiştir.

Çalışma sonucunda elde edilen veriler; JUMP istatistik paket programında tesadüf bloklarında bölünmüş parseller deneme desenine göre istatistiki analizlere tabi tutulmuş, ortalamalar arasındaki farklılıklar LSD testi ile kontrol edilmiştir.

\section{Bulgular ve Tartışma}

\subsection{Bitki boyu}

Makarnalık çeşitlere toprak ve toprak+yapraktan çinko uygulamasının bitki boyu üzerine etkisi Tablo 3'te görülmektedir. İki yılın ortalama sonuçlarına göre; topraktan çinko uygulama şeklinde, uygulanan çinko dozlarının bitki boyu üzerine etkisi istatistiki olarak önemli bulunmamış; bitki boyu 97.8-100.5 cm arasında değişmiştir. Yıllar arasında istatistiki olarak \% 1 düzeyinde önemli farklılık görülmüş, ilk yıl çinko dozlarının ve çeşitlerin ortalaması olarak bitki boyu $105.9 \mathrm{~cm}$ ölçülürken, ikinci y1l $92.8 \mathrm{~cm}$ ölçülmüsstür. Yaşanan iklimsel farklılıklar (Tablo 1) nedeniyle bitki boyu ikinci yıl kısa kalmıştır. Çeşitler arasında ise istatistiki olarak \% 1 seviyesinde farkl1lık görülmüştür. Fuatbey-2000 çeşidinin bitki boyu, çinko dozlarının ortalaması olarak $98.4 \mathrm{~cm}$; Amanos-97 çeşidinin ise, 100.2 $\mathrm{cm}$ olarak belirlenmiştir (Tablo 3).

Toprak+yapraktan çinko uygulamasının yapıldığ tarla denemesi sonuçları incelendiğinde;

Tablo 3. Toprak ve toprak+yapraktan uygulanan çinkonun makarnalık çeşitlerin bitki boyuna etkisi (cm)

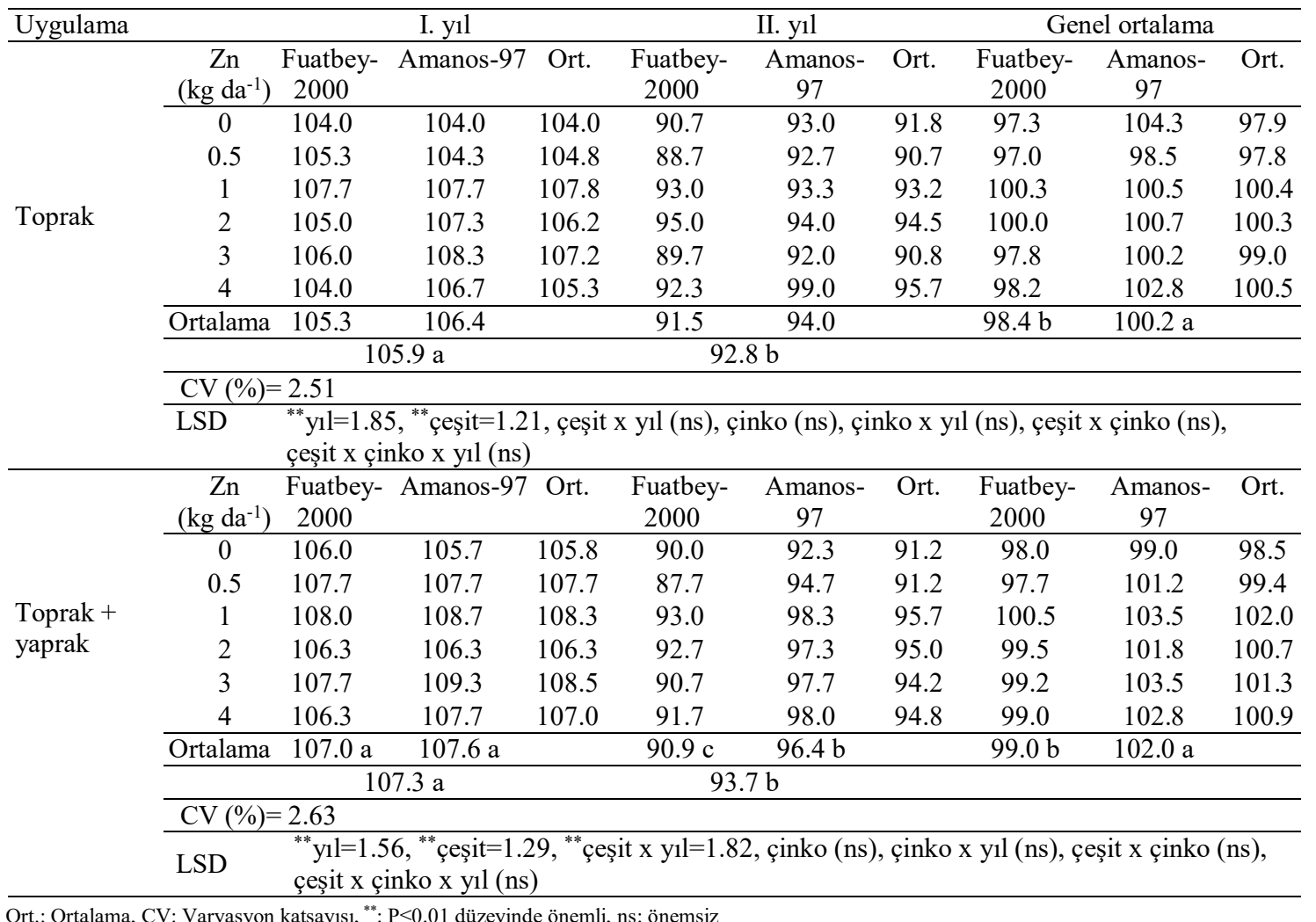

bitki boyu üzerine çinko dozlarının etkisi, topraktan uygulama şeklinde olduğu gibi istatistiki olarak önemli bulunmamıştır. Genel ortalama sonuçlarına göre, bitki boyu 98.5-100.9 cm arasında değerler almıștır. Yıllar arasında istatistiki olarak fark ( $\left.\begin{array}{ll}\% & 1\end{array}\right)$ görülmüştür. İlk yıl, çinko dozlarının ve çeşitlerin ortalaması olarak bitki boyu $107.3 \mathrm{~cm}$ ölçülürken; ikinci yıl, $93.7 \mathrm{~cm}$ 
olarak belirlenmiştir. Çeşitler arasında istatistiki olarak \% 1 düzeyinde önemli farklılık saptanmıştır. Buna göre, Fuatbey-2000 çeşidinin bitki boyu çinko dozlarının ortalaması olarak 99.0 $\mathrm{cm}$ ile en düşük, Amanos-97 çeşidinin bitki boyu ise $102.0 \mathrm{~cm}$ ile en yüksek değerler göstermiştir. Araştırmada ayrıca, çeşit x yıl interaksiyonu \% 1 düzeyinde önemli bulunmuştur (Tablo 3 ).

Çinko noksanlığı, kurak ve ani sıcaklıkların yaşandığı yıllarda erken görülürken, ilkbaharı yağışlı ve serin geçen yıllarda daha geç devrelerde ortaya çıkmaktadır. $\mathrm{Bu}$ nedenle çinko uygulamasının, çinko noksanlığının erken görüldüğü durumlarda başakta dane sayısı ve bitki boyu üzerine olumlu etkide bulunduğu, geç çıktığ 1 durumlarda ise bin dane ağırlığı üzerinde olumlu etkiler bıraktığı bildirilmiştir (Özbek ve Özgümüş, 1998). Sade ve ark. (1996) tarafindan yürütülen bir araştırmada, Gerek-79 ekmeklik buğday çeşidine, yapraktan $\mathrm{ZnSO}_{4}$ formunda uygulanan çinkonun etkileri araştırılmıştır. Farklı bölgelerde yürütülen bu çalışmada en düşük başak sayısı ve bitki boyu değerlerini kontrol parselleri vermiş, bu karakterlerde çinko uygulamasıyla artışlar sağlandığı bildirilmiştir.

\section{2. Başak sayısı}

Çinkonun iki farklı uygulama (toprak ve toprak+yaprak) şekillerinde, çinko dozlarının ve çeşitlerin metrekarede başak sayısı (adet) üzerine etkisi Tablo 4'te görülmektedir.

İki yılın ortalama sonuçlarına göre; farklı çinko dozlarının topraktan uygulandığ 1 denemede, $\mathrm{Zn}$ dozlarının buğday bitkisinin başak sayısı üzerine etkisi istatistiki olarak çok önemli ( $\% 1$ 1) bulunmuştur. Topraktan uygulanarak verilen çinko dozlar1, kontrole göre metrekaredeki başak sayısını arttırmıştır. Başak sayısında en fazla artış \% 10.5 oranında topraktan $2 \mathrm{~kg} \mathrm{Zn} \mathrm{da}{ }^{-1}$ uygulamasiyla elde edilmiştir. Bununla birlikte, kontrol konusu $(0$ $\mathrm{kg} \mathrm{Zn} \mathrm{da}{ }^{-1}$ ) hariç diğer Zn dozları arasında başak sayısı bakımından istatistiksel açıdan farklılık görülmemiştir (Tablo 4). Benzer şekilde diğer araştırmalarda (Yılmaz ve ark., 1995; Ekiz ve ark., 1998a; Ekiz ve ark., 1998b) da çinko uygulamasının metrekarede başak sayısı üzerinde etkili olduğu ve arttırdığı bildirilmiştir. Ceylan ve ark. (1998) tarafindan yürütülen bir araştırmada; $\% 0, \% 0.2, \% 0.4$ ve $\% 0.6$ oranlarında yapraktan uyguladıkları çinkonun Lirasa-92 ve Cumhuriyet75 buğday çeşitlerindeki etkilerini incelemişlerdir.

Tablo 4. Toprak ve toprak+yapraktan uygulanan çinkonun başak sayısı (adet) üzerine etkisi

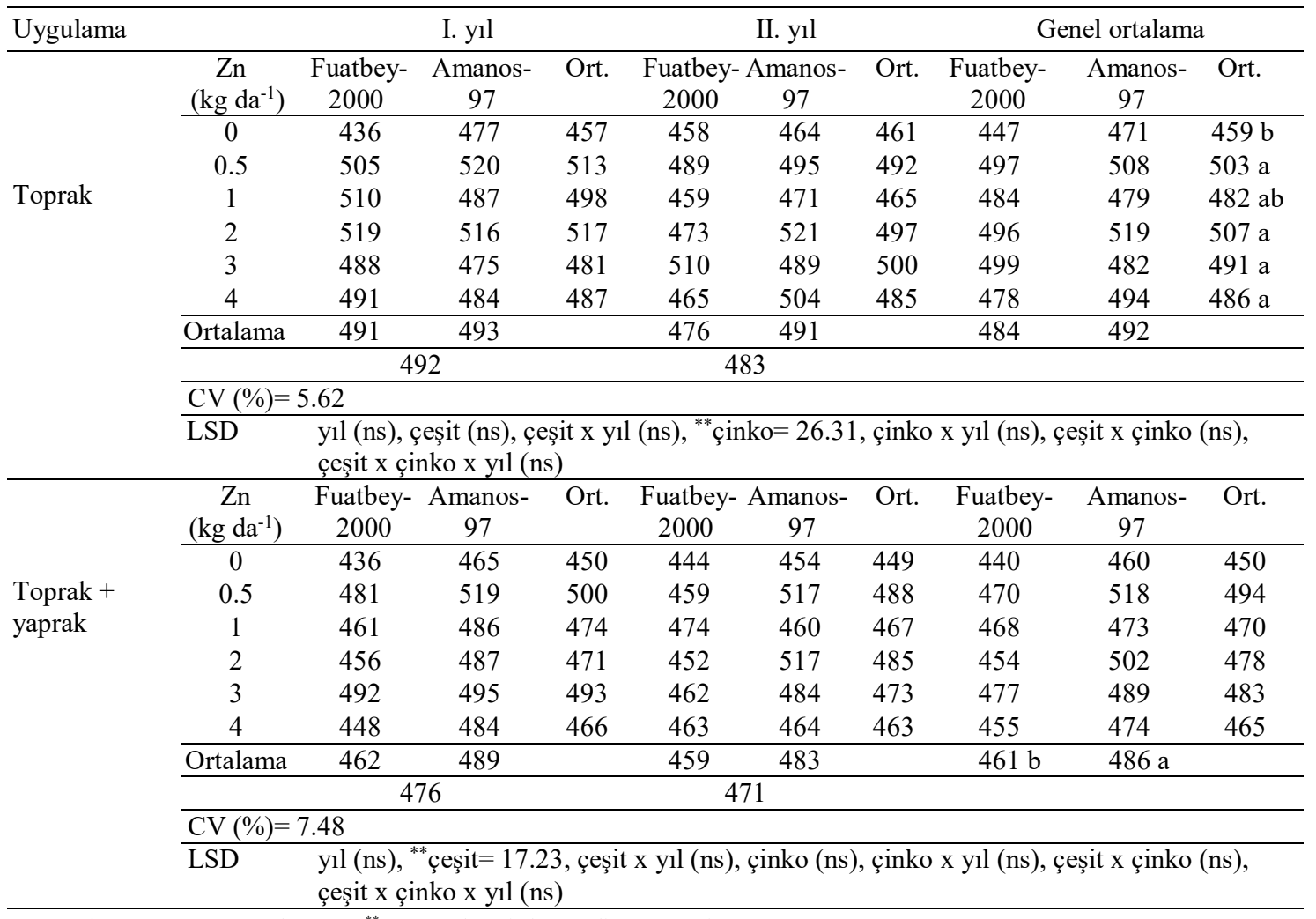

Ort.: Ortalama, CV: Varyasyon katsayısı, ${ }^{* *}: \mathrm{P} \leq 0.01$ düzeyinde önemli, ns: önemsiz 
Araştırma sonucunda ortalama değerler üzerinden \% $0.6 \mathrm{Zn}$ dozunun $\mathrm{m}^{2}$ 'de başak sayısında \% 39 oranında artış sağladığı belirtilmiştir. Toğay ve ark. (2005) tarafından yürütülen çalışmada da çinko uygulamasının metrekarede başak sayısını arttırdığ 1 fakat bunun istatistiki olarak önemsiz olduğu bildirilmiştir.

Topraktan çinko uygulamalarında, iki yılın sonuçlarına göre çeşitler arasında istatistiki açıdan farklılık görülmemiş; Fuatbey-2000 çeşidinde çinko dozlarının ortalaması olarak metrekarede 484 adet, Amanos-97 çeşidinde ise 492 adet başak sayısı tespit edilmiştir (Tablo 4).

Toprak+yaprak çinko uygulamasının yapıldığı tarla denemesi sonuçları incelendiğinde (Tablo 4); metrekaredeki başak sayısı bakımından çinko dozları arasında istatistiki olarak farklılık görülmez iken, çeşitler arasında \% 1 düzeyinde önemli farklılık belirlenmiştir. Fuatbey-2000 çeşidinin başak sayısı 461 adet $\mathrm{m}^{-2}$, Amanos-97 çeşidinin başak sayısı ise 486 adet $\mathrm{m}^{-2}$ olarak saptanmıştır (Tablo 4).

\subsection{Biyolojik verim}

İki yılın ortalama sonuçlarına göre, hem topraktan ve hem de toprak+yapraktan çinkonun uygulandığı deneme parsellerinde; biyolojik verim bakımından gerek uygulanan çinko dozları arasında ve gerekse çeşitler arasında istatistiki açıdan farklılık ortaya çıkmamıştır. Bununla birlikte her iki uygulama şeklinde yıllar arasında istatistiki açıdan \% 1 düzeyinde önemli farklılık belirlenmiştir (Tablo 5).

Topraktan uygulanan çinko dozları, biyolojik verimde $\% \quad 4.1$ ile $\% \quad 13.1$ arasında değișen oranlarda artışlar sağlamıştır. Buna göre biyolojik verim açısından kontrole göre en fazla artış topraktan $\quad 3 \quad \mathrm{~kg} \quad \mathrm{Zn} \quad \mathrm{da}^{-1}$ uygulamasiyla elde edilmiştir. Biyolojik verim birinci yıl, $2330 \mathrm{~kg} \mathrm{da}^{-1}$ olarak belirlenirken; ikinci yıl, $2843 \mathrm{~kg} \mathrm{da}^{-1}$ olarak elde edilmiştir. Topraktan çinko dozlarının uygulama şeklinde; Fuatbey-2000 çeşidinin biyolojik verimi çinko dozlarının ortalaması olarak $2510 \mathrm{~kg} \mathrm{da}{ }^{-1}$, Amanos-97 çeşidinin ise 2662 $\mathrm{kg} \mathrm{da}^{-1}$ olarak belirlenmiştir (Tablo 5).

Toprak+yapraktan çinko uygulamasının yapıldığ 1 deneme sonuçları incelendiğinde; çinko dozlarının artışına paralel olarak genel anlamda biyolojik verim de artış eğilimi göstermiştir. Topraktan $4 \mathrm{~kg} \mathrm{Zn} \mathrm{da}{ }^{-1}$ uygulaması ile yapraktan $\%$ 0.4'lük $\mathrm{ZnSO}_{4} .7 \mathrm{H}_{2} \mathrm{O}$ solüsyonu uygulamas1, kontrole göre \% 13.25 oranında biyolojik verimde

Tablo 5. Toprak ve toprak+yapraktan uygulanan çinkonun biyolojik verim $\left(\mathrm{kg} \mathrm{da}^{-1}\right)$ üzerine etkisi

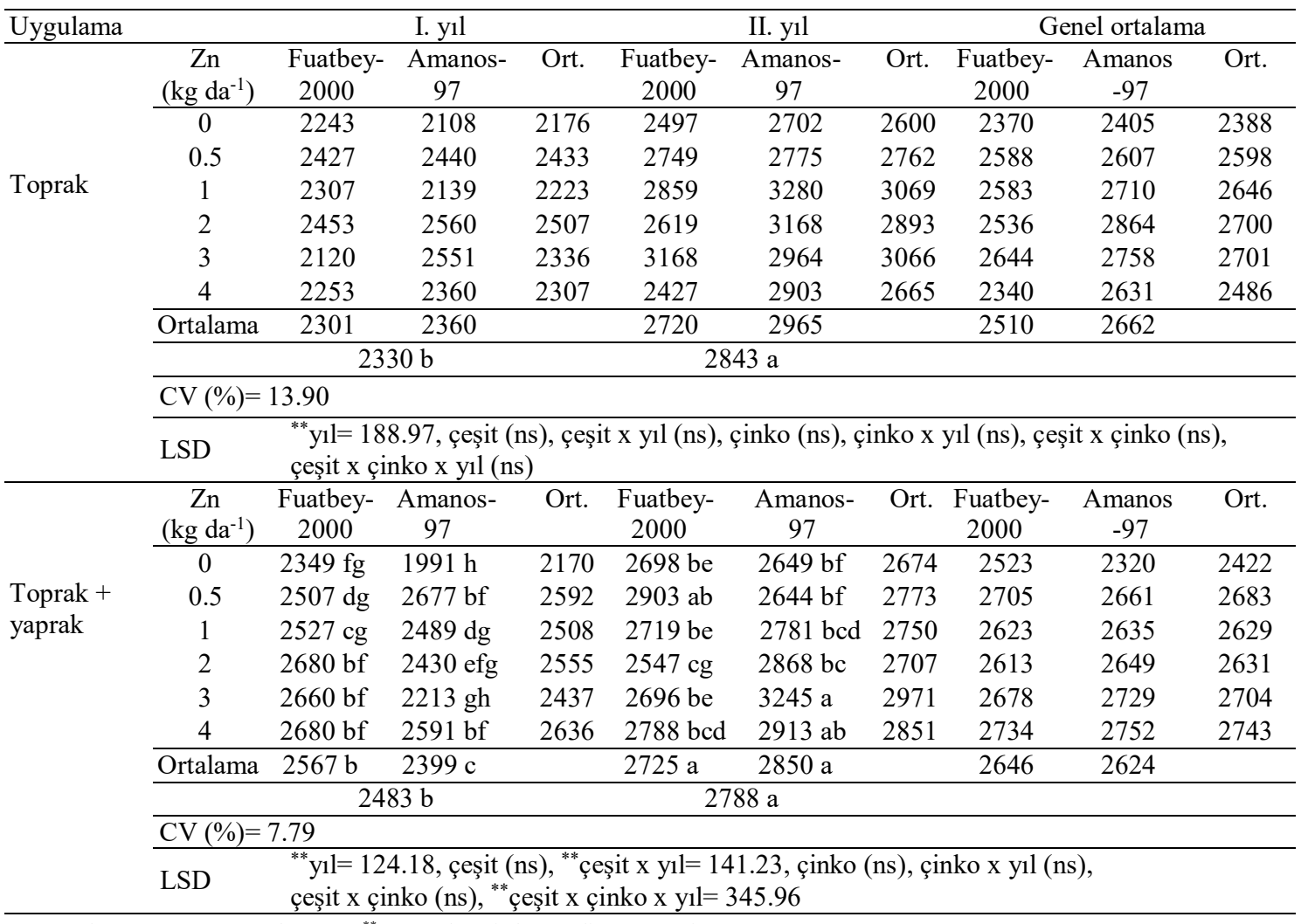

Ort.: Ortalama, $\mathrm{CV}$ : Varyasyon katsayıs1, ${ }^{* *} \mathrm{P} \leq 0.01$ düzeyinde önemli, ns: önemsiz 
artış sağlamıştır. Aynı uygulamada çeşitlerin etkisi incelendiğinde, Fuatbey-2000 ve Amanos-97 çeşidinin biyolojik verimleri sırasıyla 2646 ve $2624 \mathrm{~kg} \mathrm{da}^{-1}$ olarak belirlenmiştir. Çalışmada, çeşit $\mathrm{x}$ yıl interaksiyonu ve çeşit $\mathrm{x}$ çinko $\mathrm{x}$ yıl interaksiyonu da istatistiki açıdan çok önemli (\% 1) bulunmuştur. Toprak+yapraktan çinko uygulanması şeklinde; ilk yıl biyolojik verim 2483 $\mathrm{kg} \mathrm{da}^{-1}$ olarak ölçülürken, ikinci yıl $2788 \mathrm{~kg} \mathrm{da}^{-1}$ olarak saptanmıştır (Tablo 5).

\subsection{Sap verimi}

Makarnalık

çeşitlere toprak ve toprak+yapraktan çinko uygulamasının sap verimi üzerine etkisi Tablo 6'da sunulmuştur.

İki yılın ortalama sonuçlarına göre, çinko dozlarının her iki uygulama şeklinde de makarnalık buğdayın sap verimi üzerine etkisi istatistiki olarak önemli bulunmamıştır. Topraktan uygulama şekli incelendiğinde, sap veriminde $\% \quad 7.3$ ile \% 17.9 arasında değişen oranlarda artışlar meydana gelmiştir. Sap veriminde kontrole göre en fazla artış topraktan $3 \mathrm{~kg} \mathrm{Zn} \mathrm{da}{ }^{-1}$ uygulamasıyla elde edilmiştir. Toprak uygulamasına benzer şekilde toprak+yapraktan çinko uygulamalarında da sap veriminde kontrole göre artışlar sağlanmış; bu artışlar, \% 7.9 ile \% 15.6 arasında değişen oranlarda meydana gelmiştir (Tablo 6). Sayed ve ark. (1988), Zn uygulamasının buğdayın sap verimi üzerine önemli bir etkisinin olmadığını bildirmişlerdir.

Çeşitler arasındaki durum incelendiğinde; topraktan çinkonun verildiği uygulama şeklinde, çeşitler arasında istatistiki olarak \% 1 düzeyinde önemli farklılık görülmüş; Fuatbey-2000 çeşidinin sap verimi $1702 \mathrm{~kg} \mathrm{da}^{-1}$ ile en düşük, Amanos-97 çeşidinin sap verimi ise $1878 \mathrm{~kg} \mathrm{da}^{-1}$ ile en yüksek değeri göstermiştir. Toprak+yaprak uygulama şeklinde ise, çeşitler arasında istatistiki olarak farklılık görülmemiş; Fuatbey-2000 çeşidinin sap verimi $1789 \mathrm{~kg} \mathrm{da}^{-1}$, Amanos-97 çeşidinin sap verimi ise $1828 \mathrm{~kg} \mathrm{da}^{-1}$ olarak belirlenmiştir (Tablo 6).

Araştırmada; topraktan çinkonun uygulama şeklinde, çeşit x yıl interaksiyonu \% 5 düzeyinde; toprak+yapraktan uygulama şeklinde ise \% 1 düzeyinde önemli farklılık tespit edilmiştir. Yıllar arasında ise her iki uygulama yönteminde de istatistiki olarak \% 1 düzeyinde önemli farkl1lık saptanmıştır (Tablo 6).

Tablo 6. Toprak ve toprak+yapraktan uygulanan çinkonun sap verimi $\left(\mathrm{kg} \mathrm{da}^{-1}\right)$ üzerine etkisi

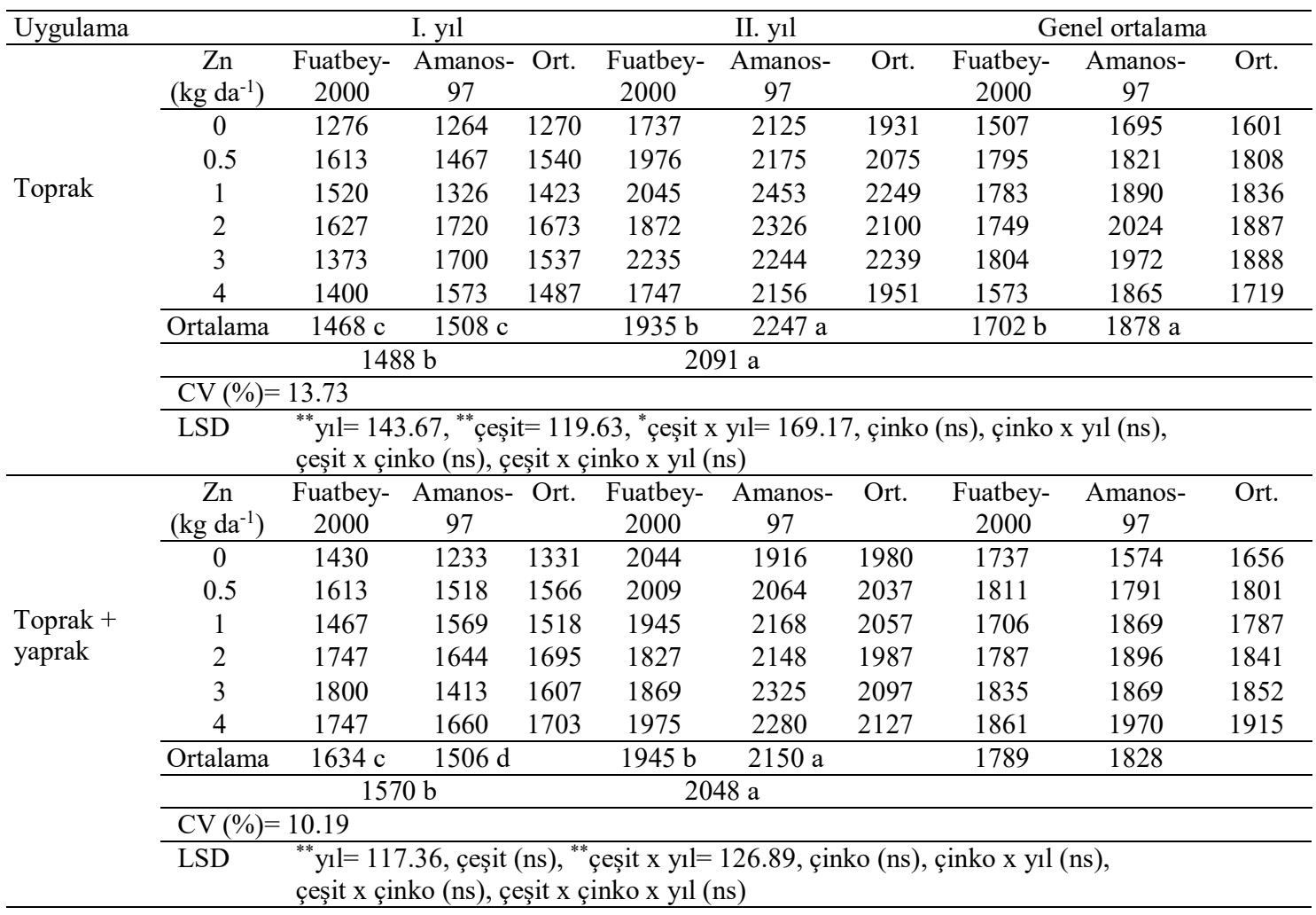

Ort.: Ortalama, CV: Varyasyon katsayıs1, ${ }^{*}: \mathrm{P} \leq 0.05$ düzeyinde önemli, ${ }^{* *}: \mathrm{P} \leq 0.01$ düzeyinde önemli, ns: önemsiz 


\subsection{Hasat indeksi}

Makarnalık çeşitlere, toprak ve toprak+yapraktan çinko uygulamasının hasat indeksi üzerine etkisi Tablo 7'de verilmiștir. İki yılın ortalama sonuçlarına göre, topraktan çinko dozları uygulamasının hasat indeksi üzerine etkisi istatistiki olarak önemli bulunmamış ve hasat indeksi \% 30.0-31.3 arasında değişmiştir. Yaşanan iklimsel faktörlerden dolayı yıllar arasında istatistiki olarak \% 1 düzeyinde önemli farklılık görülmüştür. Çeşitler arasında ise istatistiki olarak fark görülmemiştir. İki yıllık birleşik analiz sonuçlara göre; Fuatbey-2000 çeşidinin hasat indeksi \% 31.5, Amanos-97 çeşidinin ise \% 30.0 olarak belirlenmiştir (Tablo 7).

Toprak+yapraktan çinko dozları uygulamasının hasat indeksi üzerine etkisi istatistiki olarak önemli bulunmamıştır. Hasat indeksi \% 30.6-33.5 arasında değerler almıştır. Yıllar arasında ise istatistiki olarak \% 1 düzeyinde önemli farklılık görülmüştür. Çeşitlerin tepkileri incelendiğinde; ele alınan çeşitler arasında istatistiki olarak çok önemli (\% 1) farklılık tespit edilmiştir. Fuatbey2000 çeşidinin hasat indeksi \% 32.5, Amanos-97 çeşidinin ise hasat indeksi \% 30.8 olarak belirlenmiştir (Tablo 7).

Tablo 7. Toprak ve toprak+yapraktan uygulanan çinkonun hasat indeksi (\%) üzerine etkisi

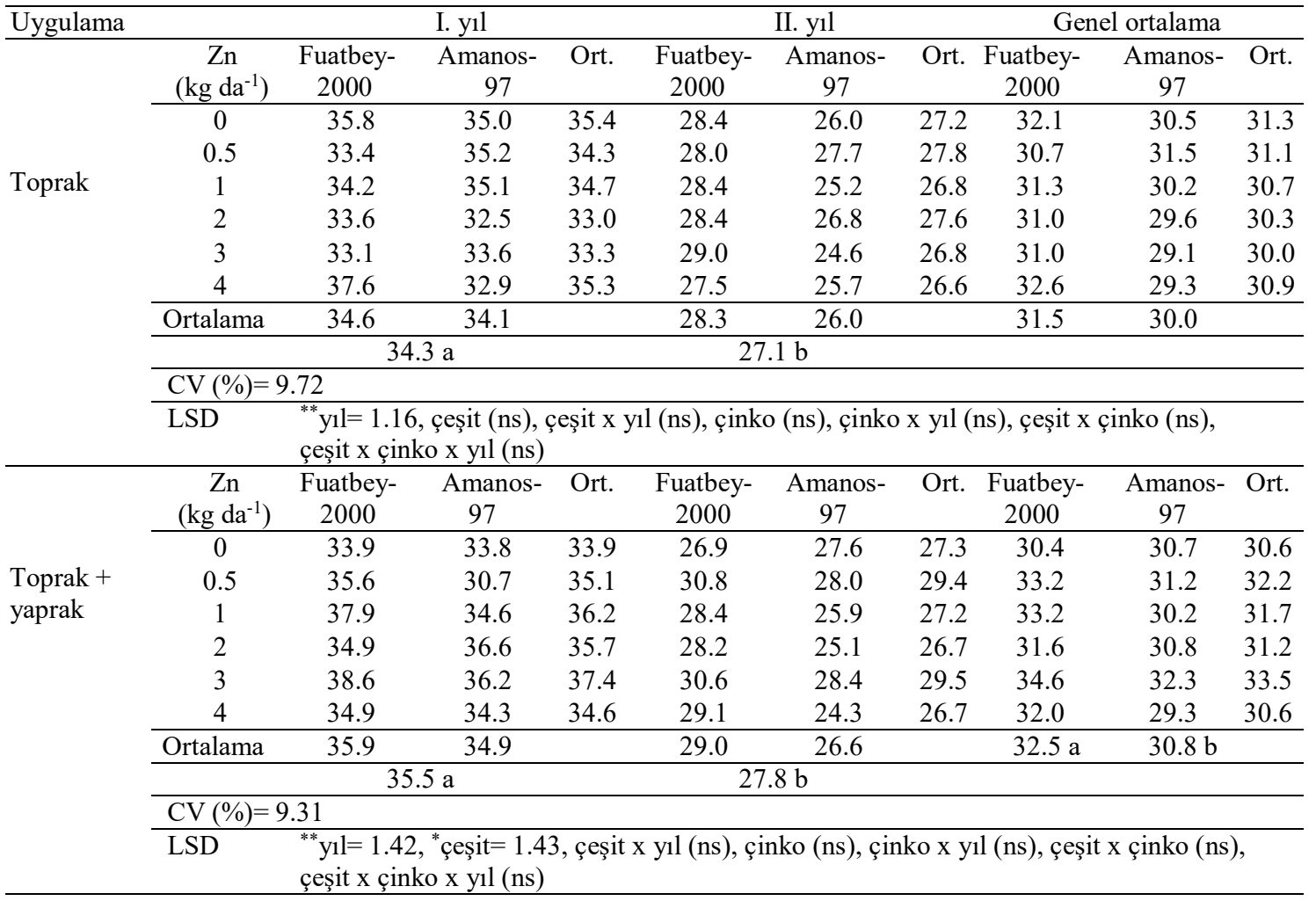

Ort.: Ortalama, $\mathrm{CV}$ : Varyasyon katsayısı, ${ }^{*}: \mathrm{P} \leq 0.05$ düzeyinde önemli, ${ }^{* *}: \mathrm{P} \leq 0.01$ düzeyinde önemli, ns: önemsiz

$\mathrm{Bu}$ araştırmada hem toprak hem de toprak+yapraktan çinko uygulamasının hasat indeksi üzerine etkisi istatistiki olarak önemsiz bulunmuştur. Benzer şekilde yapılan bazı araştırmalarda da çinko sülfat uygulamasının hasat indeksi üzerindeki etkisinin önemsiz olduğu bildirilmiștir (Gezgin, 1998). Sayed ve ark. (1988)'nın yaptıkları çalışmada ise; çinko uygulamasının tane verimine olumlu etki yaptığını, sap verimini etkilemediğini, fakat, hasat indeksinin çinko uygulaması ile arttığına işaret etmişlerdir.

\subsection{Bin tane ağırlığı}

Genel ortalama sonuçlarına göre; topraktan çinko dozları uygulamasının bin tane ağırlığını kontrole göre istatistiki olarak çok önemli (\% 1) derecede arttırdığ 1 belirlenmiştir. Ancak, $2 \mathrm{~kg} \mathrm{Zn}$ $\mathrm{da}^{-1}$ dozunda buğday tanesinin bin ağırlığında bir miktar azalış, sonraki dozlarda ise tekrar artış eğiliminde olduğu görülmüştür. En yüksek bin tane ağırlığ $53.4 \mathrm{~g}$ ile topraktan $4 \mathrm{~kg} \mathrm{Zn} \mathrm{da}{ }^{-1}$ uygulamasından elde edilmiş ve kontrole göre \% 5.32 oranında artıș meydana gelmiștir. Bununla birlikte, çinkonun $4 \mathrm{~kg} \mathrm{Zn} \mathrm{da}^{-1}$ ile $0.5,1$ ve $3 \mathrm{~kg} \mathrm{Zn}$ $\mathrm{da}^{-1}$ çinko dozları arasında bin tane ağırlı̆ 1 
yönünden farklılık, istatistiki olarak önemsiz bulunmuştur. Toprak+yapraktan çinko uygulamasında ise, bin tane ağırlığ 1 yönünden çinko dozları arasındaki farklılık istatistiki olarak önemsiz çıkmıştır. Buna rağmen kontrole göre artışlar meydana gelmiş ve bin tane ağırlığı 49.9$52.3 \mathrm{~g}$ arasında değişiklik göstermiştir (Tablo 8).

İki yılın birleştirilmiş varyans analizleri sonucunda; incelenen çeşitler arasında topraktan uygulama şeklinde istatistiki olarak \% 1 düzeyinde önemli farklılık görülürken; toprak+yaprak uygulamalarında çeşitler arasında istatistiki olarak fark görülmemiştir. Topraktan uygulama şeklinde, Fuatbey-2000 çeşidinin bin tane ağırlı̆̆ $53.0 \mathrm{~g}$, Amanos-97 çeşidinin bin tane ağırlığ $51.4 \mathrm{~g}$; toprak+yaprak uygulama şeklinde ise çeşitlerin bin tane ağırlığı sirasiyla 51.8 ve 50.9 g olarak belirlenmiştir (Tablo 8).

Araştırmada; her iki çinko uyulama yönteminde, yıllar arasında iklim faktörlerinden kaynaklanan sebeplerden dolayı istatistiki olarak \% 1 düzeyinde önemli farklılık görülmüştür. Ayrıca, topraktan çinko uygulamalarında, çeşit $\mathrm{x}$ yıl interaksiyonu da istatistiki açıdan $\% \quad 5$ düzeyinde önemli bulunmuştur (Tablo 8).

Araştırma sonucuna göre, toprak ve toprak+yapraktan çinko uygulamasının bin tane ağırlığ 1 üzerinde etkisi olumlu olmuştur. Bununla birlikte bazı araştırma bulguları ile paralel ve/veya farklılıkların da olduğu söylenebilir. Nitekim; farklı buğday genotiplerine yapraktan $\mathrm{Zn}$ uygulamasının bin tane ağırlıklarını arttırdığ (Mishra ve ark., 1989; Ekiz ve ark., 1998b), değiştirmediği (Sayed ve ark., 1988) ve azalttığ (Mandal ve Singharoy, 1989) bildirilmektedir. Yine, değişik çalışmalarda çinko uygulamasının bin tane ağırlığını önemli düzeyde arttırdığ (Özbek ve Özgümüş, 1998) belirtilirken; çinko uygulamasının bin tane ağırlığını arttırdığı, fakat, bu artışın istatistiki olarak önemli olmadığ (Taban ve ark., 1998; Ceylan ve ark., 1998; Mungan ve Doran, 2003) da bildirilmiştir. Başka bir çalışmada ise; bin tane ağırlığı açısından çeşit ortalamaları arasında fark gözlendiğini, çinko uygulamasının az da olsa bin tane ağırlığını arttırdığını, fakat bunun istatistiki olarak önemsiz olduğu belirtilmiştir (Toğay ve ark., 2005).

Tablo 8. Toprak ve toprak+yapraktan uygulanan çinkonun bin tane ağırlı̆̆ $(\mathrm{g})$ üzerine etkisi

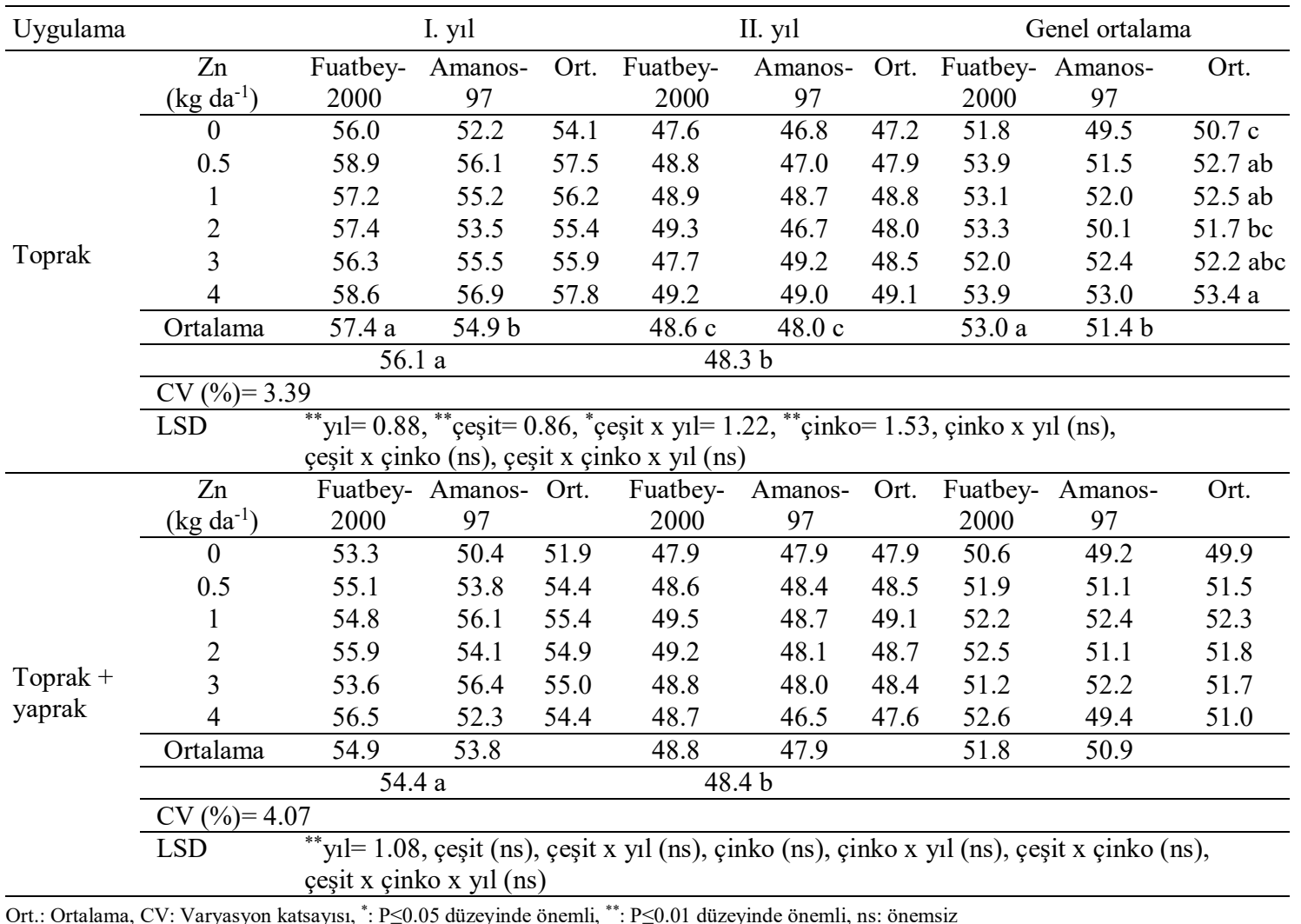




\subsection{Tane verimi}

İki yıl genel ortalama sonuçlarına göre; gerek topraktan ve gerekse toprak+yapraktan çinko dozu uygulamasının tane verimi üzerine etkisi istatistiki olarak önemli bulunmamıştır. Bununla birlikte; topraktan çinkonun $0.5 \mathrm{~kg} \mathrm{Zn} \mathrm{da}{ }^{-1}$ uygulaması kontrol konusuna göre \% 7.5, topraktan $1 \mathrm{~kg} \mathrm{Zn}$ $\mathrm{da}^{-1}$ uygulaması ile birlikte yapraktan $\%$ 0.4'lük $\mathrm{ZnSO}_{4} .7 \mathrm{H}_{2} \mathrm{O}$ solüsyonu uygulaması kontrol konusuna göre \% 13.22 oranında verim artışlarına sebep olmuştur. Her iki uygulama şeklinde tane verimi surasıyla $546-587$ ve $514-582 \mathrm{~kg} \mathrm{da}^{-1}$ arasında değişmiştir. Yaşanan iklimsel faktörlerden dolayı çinko uygulamalarının etkisi kendini gösterememiş, ancak eğilim kontrole göre artış yönünde olduğu söylenebilir (Tablo 9).

Yaşanan iklimsel faktörlerden dolayı çinkonun her iki uygulama şeklinde yıllar arasında istatistiki olarak çok önemli ( $\left.\begin{array}{ll}\% & 1\end{array}\right)$ farklılık görülmüştür. Topraktan çinkonun uygulandığı parsellerde, ilk yıl tane verimi çinko dozlarının ve çeşitlerin ortalaması olarak $640 \mathrm{~kg} \mathrm{da}^{-1}$, ikinci y1l ise $485 \mathrm{~kg}$ $\mathrm{da}^{-1}$; toprak+yapraktan çinkonun uygulandığ 1 parsellerde ise yilların verimi sirasiyla 649 ve 431 $\mathrm{kg} \mathrm{da}^{-1}$ olarak belirlenmiştir (Tablo 9). İkinci yıl ekimden sonra uzun bir süre yağış alınmadığı için bitki çıkışları yetersiz olmuştur. Zamanla toprak kurumuş ve ekilen tohumların bir kısmı açıkta kalmıștır. Açıkta kalan tohumlarda ise karınca ve kuş zararları olmuştur. Kuraklık stresi de buna eklenince yıllar arasında verim farklılıkları ortaya çıkmıştır.

Ekiz ve ark. (1998a ve 1998b) tarafindan kuraklığın ve çinko noksanlığının verimi sınırlayan bir faktör olduğu; İç Anadolu Bölgesi'nde yürütülen bir çalışmada, etkileri genotipten genotipe değişmekle birlikte $\mathrm{Zn}$ uygulamasının önemli verim artışları sağladığı bildirilmektedir. Eskişehir'de ve Konya'da yürütülen çalışmalarda da, topraktan çinko uygulamasıyla buğday veriminde sırasıyla \% 35 ve \% 69'luk artışlar elde edilmiştir (Çakmak, 1994). Değişik araştırıcılar tarafindan da benzer sonuçlar bulunmuştur (Ceylan ve ark., 1998; Özbek ve Özgümüş, 1998; Taban ve ark., 1998; Yılmaz ve ark., 1998; Mungan ve Doran, 2003; Çakmak, 2010a).

Yilmaz ve ark. (1995), çinkonun; toprak, toprak+yaprak ve tohum+yaprak uygulamalarının tane verimini \%90 oranında, yaprak ve tohum uygulamalarının ise tane verimini sırasıyla \% 51 ve 76 oranında arttırdığını belirtmişlerdir. Orta Anadolu'nun değişik bölgelerinde buğdayda çinko uygulamasının tane veriminde \% 5-550 arasında artışlar sağladığı belirtilmektedir (Çakmak ve ark., 1996). Bunun yanında, Kalaycı ve ark. (1993) ise topraktan çinko uygulaması ile arpa ve buğdayda

Tablo 9. Toprak ve toprak+yapraktan uygulanan çinkonun tane verimi $\left(\mathrm{kg} \mathrm{da}^{-1}\right)$ üzerine etkisi

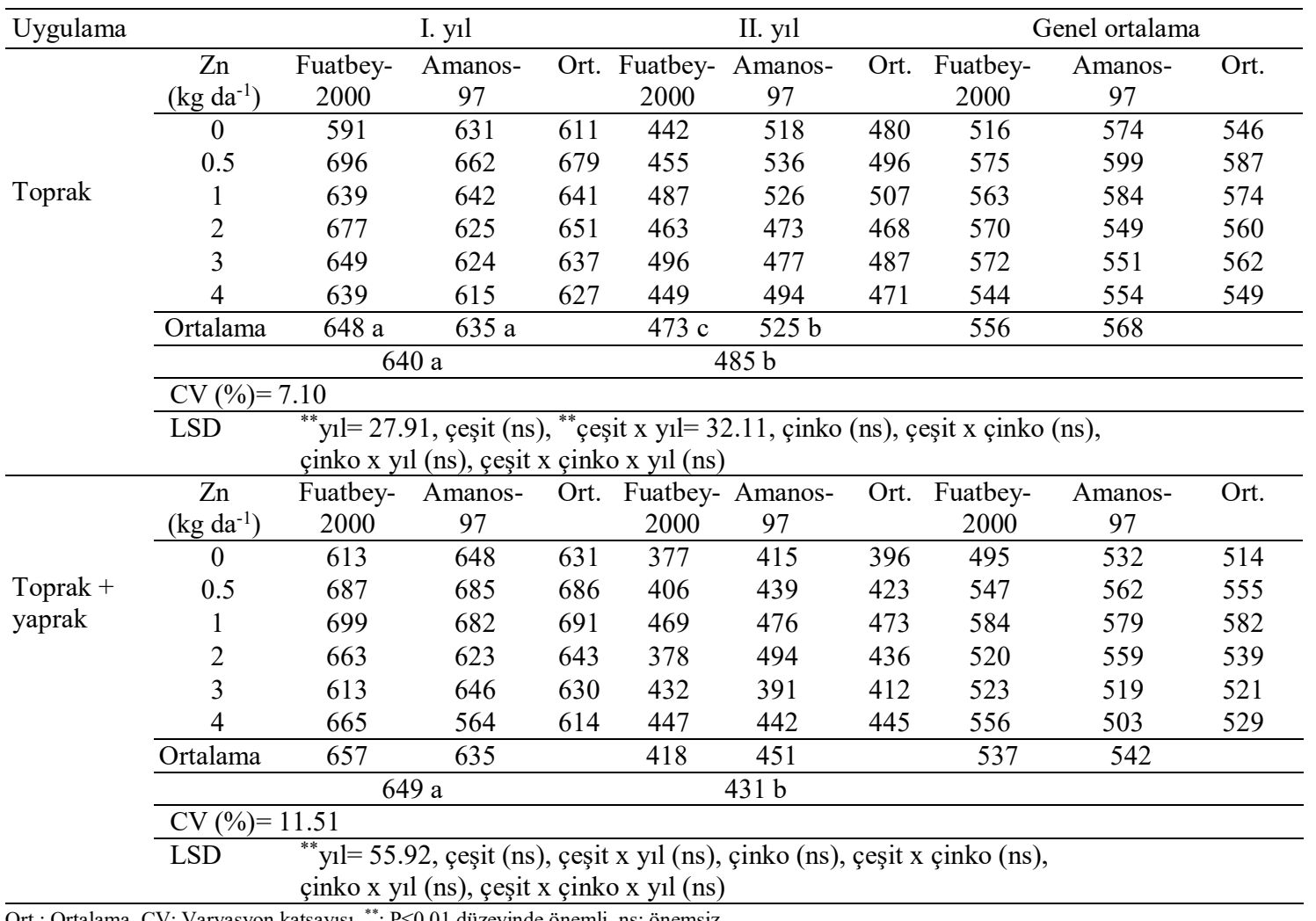

Ort.: Ortalama, $\mathrm{CV}$ : Varyasyon katsayısı, ${ }^{* *}: \mathrm{P} \leq 0.01$ düzeyinde önemli, ns: önemsiz 
\% 50-60'ın üzerinde tane veriminde önemli artışlar olduğunu bildirmektedirler. Eskişehir'de tarla denemesi ile yapılan bir çalışmada, yapraktan $\mathrm{Zn}$ uygulamasının buğdayda tane verimini \% 95'e varan boyutlarda arttırdığ 1 bildirmiştir (Kalaycı, 1993).

Çeşitler arasındaki etkileşim incelendiğinde, her iki uygulama şeklinde de çeşitler arasında istatistiksel anlamda farklılık ortaya çıkmamıştır. Her iki çinko uygulama şekillerinde, iki yılın ortalama sonuçlarına göre, Fuatbey-2000 ve Amanos-97 çeşitlerinin tane verimleri sırasıyla; 556 ve $568 \mathrm{~kg} \mathrm{da}^{-1}$ ile 537 ve $542 \mathrm{~kg} \mathrm{da}^{-1}$ olarak belirlenmiştir. Araştırmada çeşit $x \quad y 1 l$ interaksiyonu çok önemli $(\%$ 1) bulunmuştur (Tablo 9).

\subsection{Tane çinko konsantrasyonu}

Makarnalık çeşitlere toprak ve toprak+yapraktan çinko uygulamasının tane çinko konsantrasyonu üzerine etkisi Tablo 10'da görülmektedir. İki yıl genel ortalama sonuçlarına göre; topraktan çinko uygulamasının tane çinko konsantrasyonu üzerine etkisi istatistiki olarak \% 1 düzeyinde önemli bulunmuştur. Kontrol parsellerinde $\left(\begin{array}{llll}0 & \mathrm{~kg} & \mathrm{Zn} & \mathrm{da}^{-1}\end{array}\right)$ tane çinko konsantrasyonu $22.0 \mathrm{ppm}$ iken, bu miktar çinko uygulamaları ile 29.2 ppm'e kadar yükselmiştir.
Tane çinko konsantrasyonunda kontrole göre en fazla artış topraktan $3 \mathrm{~kg} \mathrm{Zn} \mathrm{da}{ }^{-1}$ uygulamasından elde edilmiş ve tane çinko konsantrasyonunda \% 32.72 oranında artış sağlanmıştır. Ancak, tane çinko içeriği yönünden; kontrol konusu hariç, çinkonun $0.5,1,2,3$ ve $4 \mathrm{~kg} \mathrm{Zn} \mathrm{da}{ }^{-1}$ dozları arasındaki farklılık istatistiki açıdan önemsiz bulunmuş ve hepsi aynı grubu oluşturmuştur (Tablo 10).

Toprak+yapraktan çinko uygulaması sonuçları incelendiğinde; tane çinko konsantrasyonu üzerine $\mathrm{Zn}$ dozlarının etkisi istatistiki olarak $\%$ düzeyinde önemli bulunmuştur. İki yıllık genel ortalama sonuçlara göre; kontrol konusunda (0 kg $\mathrm{Zn} \mathrm{da}^{-1}$ ) tane çinko konsantrasyonu $22.5 \mathrm{ppm}$ iken, bu miktar çinko uygulamaları ile 36.1 ppm'e yükselmiştir. Kontrole göre, topraktan $1 \mathrm{~kg} \mathrm{Zn} \mathrm{da}{ }^{-1}$ uygulaması ile birlikte yapraktan $\%$ 0.4'lük $\mathrm{ZnSO}_{4} .7 \mathrm{H}_{2} \mathrm{O}$ solüsyonu uygulaması çinko konsantrasyonunu \% 60.44 oranında arttırmış ve bu $\mathrm{Zn}$ dozu uygulaması istatistiki açıdan birinci grubu oluşturmuştur. Bununla birlikte, $1 \mathrm{~kg} \mathrm{Zn} \mathrm{da}{ }^{-1}$ dozu ile $0.5,2$ ve $3 \mathrm{~kg} \mathrm{Zn} \mathrm{da}^{-1}$ dozları arasında tane çinko içeriği yönünden istatistiksel olarak farklılık önemsiz çıkmıştır (Tablo 10).

$\mathrm{Bu}$ araştırma sonucunda, hem toprak ve hem de toprak+yapraktan çinko uygulaması tane çinko konsantrasyonunu arttırmıştır. Benzer sonuçlar

Tablo 10. Toprak ve toprak+yapraktan uygulanan çinkonun tane çinko konsantrasyonu (ppm) üzerine etkisi

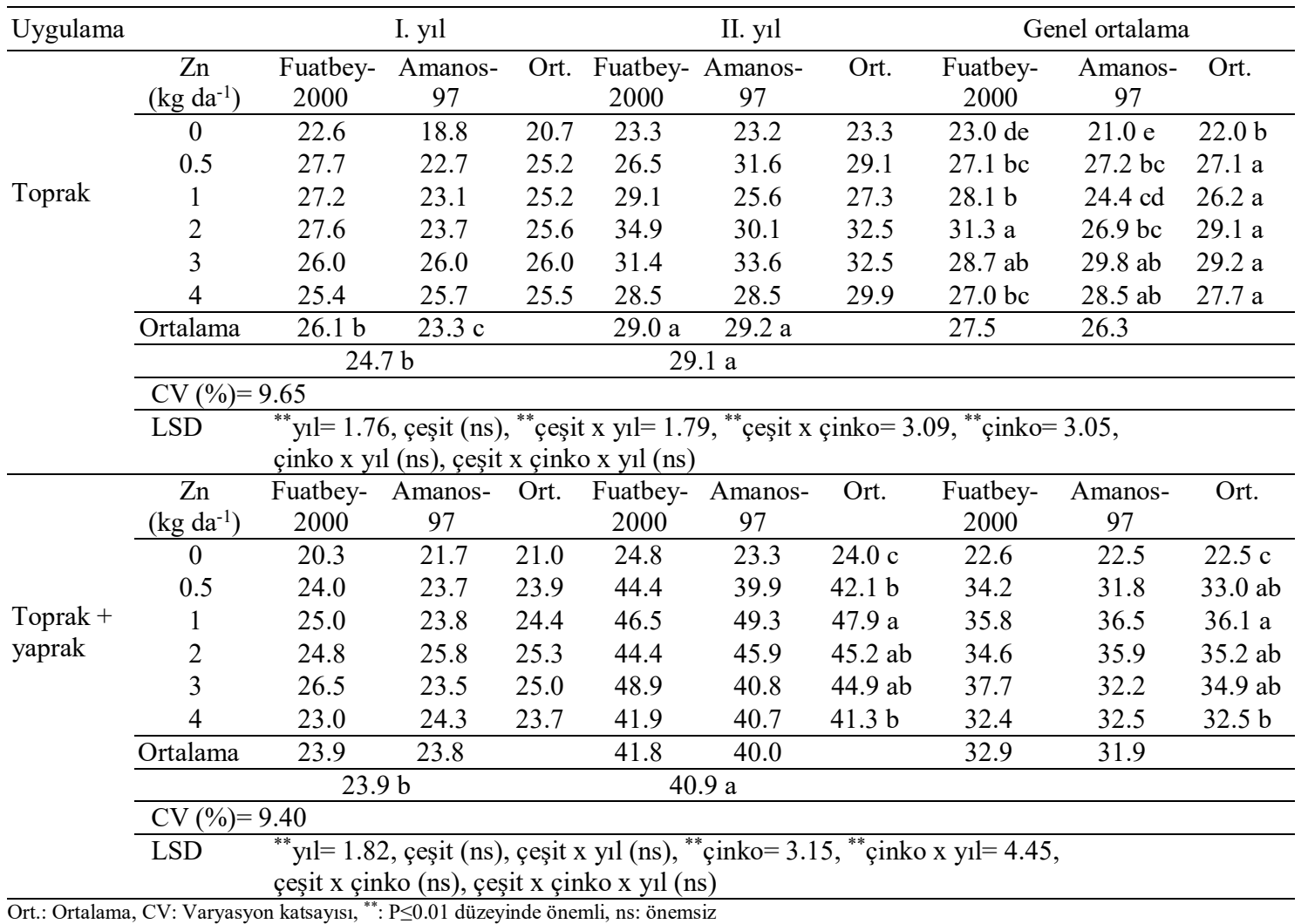


diğer araștırmalarda da elde edilmiștir. Yılmaz ve ark. (1997) tarafindan yürütülen çalışmalarda topraktan, yapraktan, tohumdan veya bunların kombinasyonu halinde yapilan $\mathrm{Zn}$ uygulamalarından genotip ve türlere göre değişmekle birlikte tane verimi, bitki ve tane $\mathrm{Zn}$ konsantrasyonlarında önemli artışlar elde edilmiştir. Yapılan araştırmada, çinko noksanlığını gidermek için en uygun çinko uygulama yönteminin toprak+yaprak uygulaması olduğu, bu uygulama ile hem tane verimi ve hem de tane $\mathrm{Zn}$ konsantrasyonunda önemli artışlar elde edildiği belirtilmiștir (Ekiz ve ark., 1998a). Yapılan çalışmalarda, yapraktan çinko gübrelemesi ile günlük çinko alımına katkı sağlayan tüm tanenin ve özellikle endospermin çinko konsantrasyonunun arttığı belirtilmiştir (Jiang ve ark., 2007; Çakmak ve ark., 2010b; Phattarakul ve ark., 2012; Zhang ve ark., 2012; Zou ve ark., 2012; Xue ve ark., 2012).

Yıllar arasında her iki çinko uygulama şekillerinde, tane çinko içeriği bakımından istatistiki olarak çok önemli (\% 1) farklılık görülmüştür. Topraktan çinkonun uygulandığg 1 durumda, ilk y1l tane çinko konsantrasyonu çinko dozlarının ve çeşitlerin ortalaması olarak 24.7 ppm iken, ikinci yıl 29.1 ppm olarak saptanmıştır. Toprak+yapraktan çinkonun uygulandığı işlemde ise, tane çinko konsantrasyonu yılların sırasına göre 23.9 ve 40.9 ppm olarak belirlenmiștir (Tablo 10). İlk yıl yaşanan olumsuz hava koşulları ve Şubat ayında meydana gelen şiddetli yağışlar nedeniyle araziye çıkılamamış ve kardeşlenme döneminde yapraktan uygulanması gereken çinko gübrelemesi yapılamamıştır. Sadece sapa kalkma döneminde yapraktan çinko uygulanmıştır. $\mathrm{Bu}$ durum, yıllar arasında farklılıklara neden olmuştur.

Araştırmada, çinkonun her iki uygulama şekillerinde de, çeşitler arasında istatistiki olarak farklılık görülmemiştir. Buna göre topraktan ve toprak+yapraktan çinko uygulamasının yapıldığ parsellerde, araştırmada incelenen Fuatbey-2000 ve Amanos-97 çeşitlerinin tane çinko konsantrasyonu; uygulama şekillerinin ve çeşitlerin sırasına göre, çinko dozlarının ortalaması olarak 27.5 ve 26.3 ppm ile 32.9 ve 31.9 ppm olarak belirlenmiştir. Topraktan uygulama şeklinde, çeşit x yıl interaksiyonu ve çeşit x çinko interaksiyonu ile; toprak+yapraktan çinko uygulandığ 1 işlemlerde de çinko $\mathrm{x}$ yıl interaksiyonu istatistiki açıdan \% 1 düzeyinde önemli bulunmuştur (Tablo 10).

\section{Sonuçlar}

Çinko uygulamasının makarnalık buğdayın verim ve kalite parametreleri üzerine etkilerinin incelendiği bu çalışmada; buğdayın gelişme süresince karşılaştığı problemlere rağmen; çinko uygulamaları, verim ve kaliteyi olumlu yönde etkilemiştir. Çinko uygulamalarının özellikle tane çinko konsantrasyonunu istatistiki olarak önemli derecede etkilediği tespit edilmiştir. Çinkonun çeşitlerin dayanıklılığını arttırmış olduğu gözlemlenmiştir. Araştırma sonucunda; toprakta 0.23-0.25 ppm çinko varlığında, topraktan dekara 1-2 kg çinko uygulamasının, tane çinko konsantrasyonu, verim ve verim unsurları üzerine olumlu etki yaptığı belirlenmiştir. Tane çinko konsantrasyonu üzerine ise çinkonun toprak+yaprak uygulamasının daha etkili olduğu belirlenmiştir.

\section{Teșekkür}

Projeye (Proje No: TAGEM/TA/06/03/01/002) desteklerinden dolayı; Gıda, Tarım ve Hayvancılık Bakanlığı, Tarımsal Araştırmalar ve Politikalar Genel Müdürlüğü'ne ve Doğu Akdeniz Tarımsal Araştırma Enstitü Müdürlüğü’ne teşekkür ederiz.

\section{Kaynaklar}

Alloway, B.J., 2008. Zinc in soils and crop nutrition. IZA Publications, International Zinc Association: Brussels.

Anonymous, 1954. U.S. Salinity Laboratory Staff. Diagnosis and Improvement of Saline and Alkaline Soils (Ed L.A. Richards). USDA Agriculture Handbook B, No: 60, U.S. Goverment Printing Office, Washington.

Black, R.E., Lindsay, H.A., Bhutta, Z.A., Caulfield, L.E., De Onnis, M., Ezzati, M., Mathers, C., Rivera, J., 2008. Maternal and child undernutrition: Global and regional exposures and health consequences. Lancet, 371(9608): 243-260.

Bouis, H.E., Welch, R.M., 2010. Biofortification a sustainable agricultural strategy for reducing micronutrient malnutrition in the global south. Crop Science, 50(Supplement_1), S-20.

Bouyoucous, G.J., 1952. Hydrometer method improved for making particle size at analysis of soil. Agronomy journal, 54(5): 464-465.

Brown, K.H., Rivera, J.A., Bhutta, Z., Gibson, R.S., King, J.C., Lönnerdal, B., Ruel, M.T., Sandtröm, B., Wasantwisut, E., Hotz, C., 2004. International Zinc Nutrition Consultative Group (IZiNCG) technical document, 1. Assessment of the risk of zinc deficiency in populations and options for its control. Food and Nutrition Bulletin, 25(1 Suppl 2): 99-203.

Ceylan, Ş., Akdemir, H., Oktay, M., İrget, E., 1998. Çinko uygulamalarının Lirasa-92 ve Cumhuriyet-75 buğday çeşitlerinde verim ve bazı verim kriterlerine etkisi. I. Ulusal Çinko Kongresi, 12-16 Mayıs, Eskişehir, s. 229-234. 
Çağlar, K.Ö., 1949 Toprak Su Koruma Mühendisliği. Çukurova Üniversitesi Ziraat Fakültesi, Yayın No: 108, Adana.

Çakmak, İ., 1994. Selection and characterisation of Creal genotypes with high resistance to zinc deficiency and boron toxicity and evalation of bioavailability of zinc in creals for GAP and Central Anatolia Regions. "TU-GENOTYPES" NATO Science for Stability Programme. III. Progress Report, Çukurova University, Adana.

Çakmak, İ., 2008. Enrichment of cereal grains with zinc: agronomic or genetic biofortification? Plant Soil, 302: 1-17.

Çakmak, İ., 2012. Harvest plus zinc fertilizer project: Harvest zinc. Better Crops, 96(2): 17-19.

Çakmak, İ., Kalaycı, M., Ekiz, H., Braun, H.J., Yılmaz, A., 1999. Zinc deficiency as an actual problem in plant and human nutrition in Turkey: A NATOScience for Stability Project. Field Crops Research, 60(1-2): 175-188.

Çakmak, İ., Kalaycı, M., Kaya, Y., Torun, A.A., Aydın, N., Wang, Y., Arisoy, Z., Erdem, H., Yazıc1, A., Gökmen, O., Öztürk, L., Horst, WJ., 2010b. Biofortification and localization of zinc in wheat grain. Journal of Agricultural and Food Chemistry, 58(16): 9092-9102.

Çakmak, İ., Pfeiffer, W.H., McClafferty, B., 2010a. Biofortification of durum wheat with zinc and iron. Cereal Chemistry, 87(1): 10-20.

Çakmak, İ., Yılmaz, A., Kalaycı, M., Ekiz, H., Torun, B., Eranoğlu, B., Braun, H.J., 1996. Zinc deficiency as a critical problem in wheat production in Central Anatolia. Plant and Soil, 180: 165-172.

Ekiz, H., Bağcı, S.A., Kıral, A.S., Eker, S., Gültekin, İ., Alkan, A., Çakmak, İ., 1998a. Effects of zinc fertilization and irrigation on grain yield and zinc concentration of various cereals grown in zincdeficient calcareous soils. Journal Plant Nutrition, 21(10): 2245-2256.

Ekiz, H., Öztürk, L., Bağcı, S.A., Gültekin, İ., Yılmaz, A., Çakmak, İ., 1998b. Çinko noksanlığının buğdayın kuraklık toleransı üzerine etkileri. $I$. Ulusal Çinko Kongresi, 12-16 Mayıs, Eskişehir, s. 511-517.

Erdal, İ., Yılmaz, A., Taban, S., Eker, S., Çakmak, İ., 2002. Phytic acid and phosphorus concentrations in seeds of wheat cultivars grown with and without zinc fertilization. Journal of Plant Nutrition, 25(1): 113-127.

Gezgin, S., 1998. Farklı form ve dozlarda yapraktan uygulanan çinkonun buğdayın verim ve bazı verim unsurlarına etkisi. I. Ulusal Çinko Kongresi, 12-16 Mayıs, Eskişehir, s. 213-221.

Gibson, R.S., Hess, S.Y., Hotz, C., Brown, K.H., 2008. Indicators of zinc status at the population level: A review of the evidence. British Journal of Nutrition, 99(3): 14-23.

Graham, R.D., Ascher, J.S., Hynes, S.C., 1992. Selecting zinc-efficient cereal genotypes for soils of low zinc status. Plant and Soil, 146(1-2): 241-250.
Jackson, M.L., 1959. Soil Chemical Analysis. Englewood Cliffs, New Jersey.

Jackson, M.L., 2005. Soil Chemical Analysis: Advanced Course. UW-Madison Libraries Parallel Press.

Jiang, W., Struik, P.C., Lingna, J., Van Keulen, H., Ming, Z., Stomph, T.J., 2007. Uptake and distribution of root-applied or foliarapplied $65 \mathrm{Zn}$ after flowering in aerobic rice. Annals of Applied Biology, 150(3): 383-391.

Kalayc1, M., 1993. Eskişehir'de mikroelement noksanlıklarının buğday ve arpa verimine etkileri. TİGEM Meslek İçi Semineri, 13-21 Aralık, Antalya.

Kalaycı, M., Aydın, M., Kaya, F., Özbek, V., Siirt, S., 1993. Mikro besin maddesi denemeleri. Geçit Kuşağı Tarımsal Araştırma Enstitüsü, 1992-1993 Yılı Serin İklim Tahılları Projesi Gelișme Raporu, Eskişehir.

Lindsay, W.L., Norvell, W.A., 1978. Development of a DTPA soil test for zinc, iron, manganese and copper. Soil Science Society of America Journal, 42: 421428.

Mandal, A.B., Singharoy, A.K., 1989. Selection of some wheat genotypes on Terai. Soil, Environment and Ecology, 7(4): 978-979.

Manzeke, G.M., Mtambanengwe, F., Nezomba, H., Mapfumo, P., 2014. Zinc fertilization influence on maize productivity and grain nutritional quality under integrated soil fertility management in Zimbabwe. Field Crop Research, 166: 128-136.

Mishra, S.S., Gulati, J.M.L., Nanda, S.S., Garyanak, L.M., Jenz, S.N., 1989. Micronutrient studies in wheat. Orissa Journal of Agricultural Research, 22(2): 94-96.

Mungan, S., Doran, İ., 2003. Farklı doz ve yöntemlerle uygulanan çinkonun makarnalık buğday ve arpanın verim ve verim unsurlarına etkileri. Türkiye 5. Tarla Bitkileri Kongresi, 13-17 Ekim, Diyarbakır, Cilt: 2, s. 510-515.

Olsen, S.R., Cole, C.V., Watanabe, F.S., Dean, L.A., 1954. Estimation of available phosphorus in soil by extraction with sodium bicarbonate. U.S. Department of Agriculture, Circular No. 939.

Ortiz-Monasterio, J.I., Palacios-Rojas, N., Meng, E., Pixley, K., Trethowan, R., Pena, R.J., 2007. Enhancing the mineral and vitamin content of wheat and maize through plant breeding. Journal Cereal Science, 46(3): 293-307.

Özbek, V., Özgümüş, A., 1998. Farklı çinko uygulamalarının değişik buğday çeşitlerinin verim ve bazı verim kriterleri üzerine etkileri. I. Ulusal Çinko Kongresi, 12-16 Mayıs, Eskişehir, s. 183-190.

Pahlavan-Rad, M.R., Pessarakli, M., 2009. Response of wheat plants to zinc, iron, and manganese applications and uptake and concentration of zinc, iron, and manganese in wheat grains. Communications in Soil Science and Plant Analysis, 40(7-8): 1322-1332.

Pfeiffer, W.H., Mcclafferty, B., 2007. Harvest plus: Breeding crops for better nutrition. Crop Science, 47(Suppl.3): 88-105. 
Phattarakul, N., Rerkasem, B., Li, L.J., Wu, L.H., Zou, C.Q., Ram, H., Sohu, V.S., Kang, B.S., Sürek, H., Kalaycı, M., Yazıcı, A., Zhang, F.S., Çakmak, İ., 2012. Biofortification of rice grain with zinc through zinc fertilization in different countries. Plant and Soil, 361(1-2): 131-141.

Prasad, R., Shivay, Y.S., Kumar, D., 2014. Agronomic biofortification of cereal grains with iron and zinc. Advances in Agronomy, 125: 55-91.

Sade, B., Soylu, S., Kan, A., Y1ldı, C., 1996. Farklı lokasyonlarda yapraktan uygulanan çinkonun buğdayda verim ve verim unsurları üzerine etkileri. Selçuk Üniversitesi Ziraat Fakültesi Dergisi, 10(12): 45-54.

Sayed, E., Gheith, M.S., El-Badry, O.Z., 1988. Effects of the dates of zinc application on wheat. Beyrage Zur Tropischen Landwirtshof und Veterinormadizin, 26(3): 273-278.

Sillanpaa, M., 1982. Micro Nutrients and the Nutrient Status of Soils. A Global Study. FAO Soils Bulletin, No. 48, FAO, Rome.

Singh, U., Praharaj, C.S., Singh, S.S., Bohra, A., Shivay, Y.S., 2015. Biofortification of pulses: Strategies and challenges. In Proceedings of The Second International Conference on Bio-Resource and Stress Management, Hyderabad, India, pp. 50-55.

Taban, S., Alpaslan, M., Güneş, A., Aktaş, M., Erdal, İ., Eyüpoğlu, H., Baran, İ., 1998. Değişik şekillerde uygulanan çinkonun buğday bitkisinde verim ve çinkonun biyolojik yarayışl1lığı üzerine etkisi. $I$. Ulusal Çinko Kongresi, 12-16 Mayıs, Eskişehir, s. 147-155.

Toğay, Y., Toğay, N., Kocakaya, Z., Erdal, İ., Çiğ, F., 2005. Van koşullarında çinko uygulamasinin farklı buğday çeşit ve hatlarında verim ve verim öğeleri üzerine etkisi. Türkiye VI. Tarla Bitkileri Kongresi, Araştırma Sunusu Cilt I, 5-9 Eylül, Antalya, s. 595600.

Waters, B.M., Grusak, M.A., 2008. Whole-plant mineral partitioning throughout the life cycle in Arabidopsis thaliana ecotypes Columbia, Landsberg erecta, Cape
Verde Islands, and the mutant line ysllysl3. New Phytologist, 177(2): 389-405.

White, J.G., Zasoski, R.J., 1999. Mapping soil micronutrients. Field Crop Resarch, 60(1): 11-26.

White, P.J., Broadley, M.R., 2005. Biofortifying crops with essential mineral elements. Trends Plant Science, 10(12): 586-593.

Xue, Y.F., Yue, S.C., Zhang, Y.Q., Cui, Z.L., Chen, X.P., Yang, F.C., Çakmak, İ., McGrath, S.P., Zhang, F.S., Zou, C.Q., 2012. Grain and shoot zinc accumulation in winter wheat affected by nitrogen management. Plant Soil, 361(1-2): 153-163.

Yılmaz, A., Ekiz, H., Torun, B., Aydın, A., Çakmak, İ., 1995. Determination of zinc application methods in zinc-defficient-wheat growing areas of Central Anatolia. Soil Fertilty and Fertilizer Management 9 th International Symposium of CIEC, 25-30 September, Kuşadas1, Turkey, pp. 91-95.

Yılmaz, A., Ekiz, H., Torun, B., Gültekin, İ., Karanlık, S., Bağc1, S.A., Çakmak, İ., 1997. Effect of different zinc application methods on grain yield and zinc concentration in wheat grown on zinc-deficient calcerous soils in Central Anatolia. Journal Plant Nutrition, 20(4-5): 461-471.

Yılmaz, A., Ekiz, H., Gültekin, İ., Torun, B., Barut, H., Karanlık, S., Çakmak, İ., 1998. Effect of seed zinc content on grain yield and zinc concentration of wheat grown in zinc-deficient calcareous soils. Journal of Plant Nutrition, 21(10): 2257-2264.

Zhang, Y.Q., Sun, Y.X., Ye, Y.L., Karim, M.R., Xue, Y.F., Meng, Q.F., Cui, Z.L., Çakmak, İ., Zhang, F.S., Zou, C.Q., 2012. Zinc biofortification of wheat through fertilizer application in different locations of China. Field Crop Research, 125: 1-7.

Zou, C.Q., Zhang, Y.Q., Rashid, A., Ram, H., Savaşl1, E., Arisoy, R.Z., Ortiz-Monasterio, I., Simunji, S., Wang, Z.H., Sohu, V., Hassan, M., Kaya, Y., Önder, O., Lungu, O., Yaqub Mujahid, M., Joshi, A.K., Zelenskiy, Y., Zhang, F.S., Cakmak, İ., 2012. Biofortification of wheat with zinc through zinc fertilization in seven countries. Plant Soil, 361(1-2): 119-130. 